$\begin{array}{lll}\text { Makalenin Türü / Article Type } & : \text { Araştırma Makalesi / Researh Article } \\ \text { Geliş Tarihi / Date Received } & : 10.01 .2019 \\ \text { Kabul Tarihi / Date Accepted } & : 28.01 .2020 \\ \text { Yayn Tarihi / Date Published } & : 06.03 .2020 \\ \text { dohhttps://dx.doi.org/10.17240/aibuefd.2020.20.52925-511016 }\end{array}$

\title{
ÖĞRETMEN VE ÖĞRENCİ GÖZÜNDEN BİR EV ÖDEVİ PORTRESİ
}

\author{
Çağla ALPAYAR ${ }^{1}$
}

\section{ÖZ}

Bu araştırmada, tipik ev ödevi uygulamalarının yürütüldüğü ilkokul dördüncü sınıftaki ev ödevi portresinin ortaya konulması amaçlanmaktadır. Bu amaca yönelik olarak, öğretmenin Trafik Güvenliği dersinde verilen üç farklı türdeki ödevden beklentilerinin ne olduğu ve bu beklentilerin öğrencilerde karşıllı̆ıın bulup bulmadığı araştırılmıştır. Bu nedenle de araştırma nitel araştırma deseninde yürütülmüştür. Katılımcılar, İç Anadolu Bölgesi’nde 2016-2017 eğitim öğretim yılında dördüncü sınıfta öğrenim gören 25 öğrenci ve bir öğretmendir. Araştırmanın veri toplama aracı, araştırmacı tarafından hazırlanan görüşme formlarıdır. Biri öğretmene, diğeri öğrencilere yönelik olmak üzere iki farklı görüşme formu hazırlanmıştır. Verilerin analizinde betimsel analiz yönteminden yararlanılmıştır. Buna göre öğretmen ödevleri eğitsel (derse hazırlık, ders tekrarı, değerlendirme ve genişletme) ve eğitsel olmayan (sorumluluk bilinci aşlama, araştırma becerisini geliştirme ve veli ile etkileşimi artırma) amaçlara yönelik olarak vermektedir. Öğrenciler ise ev ödevlerine yönelik genel olarak olumlu görüşlere sahiptir. Öğretmenin ev ödevi verirken oluşturduğu beklentilerin de genel anlamda öğrencilerde karşıllı̆ını bulduğu ifade edilebilir.

Anahtar Kelimeler: Ev ödevi, öğrenci görüşü, öğretmen görüşü

\section{A HOMEWORK PORTRAIT FROM A TEACHER'S AND HER STUDENTS' PERSPECTIVES}

\begin{abstract}
In this research, it is aimed to reveal a homework portrait of a fourth grade class where typical homework practices are conducted. For this purpose, it was investigated what the teacher expects from the three types of homework applied in the "Traffic Safety" lesson, and whether these expectations corresponded to the students' perspectives. Therefore, the research was carried out in qualitative research design. The study group was a teacher of a fourth grade class in the Central Anatolia Region of Turkey and her 25 students. The data collection tool of the research were the interview forms constructed by the researcher. Two different interview forms were constructed. One of them was for the teacher and the other one was for the students. In the analysis of the data, a descriptive analysis method was applied. Accordingly, the assignments are intended for instructional purposes (course preparation, course repetition and assessment) and non-instructional (development of research skills and increasing interaction with parents) by the teacher. Students have generally positive views on homework. It can be argued that the teacher' expectations from impact of assignments on the students are corresponded to the students' views in general terms.
\end{abstract}

Keywords: Homework, students' opinions', teacher's opinion

\footnotetext{
${ }^{1}$ Ankara Üniversitesi, Eğitim Bilimleri Fakültesi, alpayar@ankara.edu.tr, (10 https://orcid.org/0000-0003-3178-5560
} 


\section{GíRiş}

Eğitim ve öğretim faaliyetlerinin yürütüldüğü ortamlar olan okullar, formal öğrenmelerin merkezleridir. Ancak öğrenme okulla sınırlı değildir; bireyler, hayatlarının her anında bilgi edinmeyi sürdürürler. Öğrencilerin okul dışında da öğretim programı kapsamındaki hedeflere yönelik öğrenmelerini sürdürmelerinin bir aracı olarak ev ödevleri yaygın biçimde kullanılmaktadır. Ev ödevleri en geniş anlamda, öğrencilerin okul saatleri dışında yerine getirmeleri için öğretmenler tarafından verilen görevler olarak tanımlanabilir (Cooper, 2007). Farklı tanımlar ana hatlarıyla benzerlik göstermekle birlikte bazı araştırmacılar velilerin desteğiyle tamamlanması bazıları ise okul öğrenmeleriyle bağlantılı olması gerekliliğini vurgulamaktadır (Kidwell, 2004; Good, 1959). Bu yönüyle ödevleri, okul ve ev arasında bir köprü olarak nitelemek yanlış bir yaklaşım olmayacaktır (Corno, 1996)

Ev ödevlerinin veriliş amaçları eğitici (instructional) olan ve olmayan (non-instructional) olmak üzere iki ana başlık altında incelenebilir (Cooper, 2007). Cooper, eğitici amaçlara yönelik en sık başvurulan ödev türünün uygulama yapmak ve dersi tekrarlamak amacıyla verilen gözden geçirme ödevleri olduğunu ifade etmektedir. Bu tür ödevlerle, öğrencinin okulda işlenen konuyu pekiştirmesi ve hedef becerilerde uzmanlaşmasının desteklenmesi hedeflenmektedir (Epstein ve Becker, 1982). İkinci olarak ev ödevleri, derste edinilen ve okul ortamında bir sebeple gerçekleştirilmesi mümkün olmamış bilginin farklı bir formda kullanılmasına olanak vererek geliştirilmesi (extention) amacına hizmet etmektedir. Öğretmenler tarafından sıklıkla tercih edilen bu amaçlı ödevlere, davranışın veya becerinin öğrenciye kazandırılmasından hemen sonra başvurulmaktadır (Lee ve Pruit, 1979 ). Ödev türleri arasından öğrenci başarısı üzerinde en etkili olanlar, o gün işlenmiş konuyu kapsayan ödevlerdir (NCTM, 2008). Üçüncü olarak ev ödevlerine, bir konuya başlamadan önce öğrencilerin hazır bulunuşluk düzeylerini artırmak ve öğrenmelerine zemin hazırlamak amacıyla başvurulmaktadır. En yaygın uygulanışı işlenecek konunun dersten önce öğrencilere okutulmasıdır. Bir diğer ödev grubu geliştirici ödevlerdir. Bu ödevler, beceri ve bilgi alanının birlikte kullanılarak ürün ortaya konmasını sağlayarak tamamlama (integration) eylemlerine de olanak vermektedir. Böyle ödevlerle öğrencilerin bilgi ve becerilerini yeni durumlarda uygulaması sağlanmakta ve öğrencilerin üst düzey düşünme becerilerinin geliştirilmesi amacına da hizmet etmektedir (Babadoğan, 2003). Bunun yanı sıra ev ödevlerine, kütüphane materyallerinin nasıl kullanacağı gibi çeşitli öğrenmelerin sınırlı ders saatinin dışında gerçekleştirilmesi amacına yönelik başvurulmaktadır (Paulu, 1998). Öğrencilerin fikirlerini geliştirmek ve araştırma yapmalarını sağlamak için de ev ödevleri verilmektedir (Ersoy ve Anagün, 2009; Hizmetçi ve İflazoğlu, 2006; Yücel, 2004).

Ev ödevlerinin, eğitsel olmayan amaçları da vardır. Bu tür ödevler, öğrencilerin bilişsel gelişiminin yanında ev yaşamları üzerinde de etkilidir (Alleman, Knighton, Brophy, Ley ve Botwinski, 2010). Anne-babaların desteğini gerektiren bu çalışmalar, hem çocuklarının okul yaşamına katılmalarına hem de öğrencilerin okul-ev bağlantısının farkına varmalarına olanak vermektedir (Cooper, 2007). Ayrıca okuldaki faaliyetlerin aksine ev ödevlerini yaparken daha az denetim ve zaman kısıtlaması bulunması sebebiyle öğrencileirn öz-disiplin, öz-yönlendirme, zaman yönetimi ve bağımsız problem çözme becerisi sergilemeleri gerekmektedir. Bu sebeple, özellikle ilkokul çağındaki öğrenciler için ödevlerin daha çok çalışma alışkanlığı kazanma, okula karşı olumlu tutum geliştirme aracı olarak kullanılması önerilmektedir (Cooper ve Hedges, 1994). Ancak ev ödevlerini desteklemeyen araştırmacılar, eğitsel olmayan etkilerinin ödev miktarına bağlı olarak değişkenlik gösterdiğini ifade etmektedir. Buna göre ödevlerin miktarı arttıkça, öğrencilerde yılgınlık belirmekte; buna bağlı olarak artan kaygı da beklenenin aksine okula karşı olumsuz tutumlara yol açmaktadır (Berberoğlu, 2005). Ebeveyn ile etkileşimin güçlenmesinin bir aracı olarak görülürken aynı zamanda anne babaların tamamlanması için öğrencilerin üzerinde baskı kurmasına sebep olmaktadır (Cooper, 2007). Bunun önüne geçmek için ödevlerin tasarlanırken katkısının ön planda tutulması ve makul miktarlarda verilmesi önerilmektedir (Kohn, 2006). Aksi durumda öğrencinin ödevlerle doyuma ulaşması sebebiyle akademik materyallere ilgisini kaybedebilmesi ve fiziksel ya da duygusal olarak yorgunluk hissedebilmesidir (Cooper, 2003). Ödev yoğunluğu sebebiyle boş zamanları azalmakta ve sosyalleşmeye zaman ayırma olanakları ortadan kalkabilmektedir. Son olarak, ödevi yapmakta güçlük çeken öğrenciler kopya ya da intihale yönelebilmektedir.

Ev ödevlerinin belirlenen amaçlara hizmet edebilmesi ve etkili olabilmesi için sahip olması gereken bazı özelliklerden söz edilebilir. Öncelikle, öğrencilerin ödevlerin anlamlı ve önemli olduğunu bilmeleri güdülenmelerini artırmaktadır (Kohn, 2006; Paulu, 1998). Öğretmenler de gerekliliğinden emin olmadıkları ödevleri vermemeli ve öğrencileri ödevin amacı konusunda bilgilendirmelidir. $\mathrm{Bu}$ durum öğrencilerin güdülenmeleri artmakta ve daha anlamlı öğrenmeler gerçekleştirmeleri mümkün olmaktadır (Sullivan ve Sequare, 1996). Ödevlerin etkililiğinde belirleyici olan bir diğer özellik, güçlük derecesidir. Ödevlerde orta güçlükteki sorulara yer verilmesi eğilimi olsa da sorular öğrencilerin başarı düzeylerine göre belirlenmelidir (Cooper, Robinson ve Patall, 2006). Bu noktada ödevlerin sadece tekrar ya da derse hazırlık amacına değil uygulama ve bütünleştirme amacına da hitap etmesi hedeflenmelidir. Öğrencileri zorlayan ya da yeni ürün ortaya koymalarını gerektirecek ödevler verilmelidir. Ödevler, sıklıkla uygulanmalı ancak kısa sürede tamamlanabilir nitelikte olmalıdır (Cooper, 2001). Ağırlıklı olarak Amerika örnekleminde yürütülen pek çok araştırmaya göre tamamlanması için uzun süre gereken ödevler etkili değildir (Cooper ve diğerleri, 2006). Uzun ev ödevleri 
yılgınlı̆ga yol açmaktadır. Genel anlamda incelendiğinde, öğretmenlerin okuduğunu anlamaya yönelik verdikleri ödev sıklığının öğrencileirn bu alandaki başarını açıklamada en etkil değişkenlerden bir olduğu görülmektedir (Aslanoğlu ve Kutlu, 2015). Verilecek ev ödevinin sıklı̆̆ı ve kapsamı sınıf düzeyine bağlı olarak belirlenmelidir. Bu miktar, öğretmenin ortalama başarı düzeyindeki bir öğrencinin ödevi tamamlayacağına süreye yönelik yaptı̆̆ı tahminle belirlenebilir. Ev ödevinin miktarı için en uygun ölçüt "sınıf düzeyi x 10" dakikada tamamlanacak yoğunlukta olmasıdır (Cooper, 2003). Birinci sınıftaki öğrencinin her dersin ödevi için harcayacağı günlük ideal süre 10 dakika iken, lise öğrencisi bir ders için en fazla iki saat harcamalıdır. Buna bağlı olarak 3.-6. sınıf düzeylerindeki öğrenciler bir günde 30-60 dk'da tamamlanabilecek ödevlerin üstesinden gelebilir; daha fazlas1 ödevin etkisini azaltmaktadır (Henderson, 1996'dan aktaran Cooper, 2003: 120). Ev ödevi uygulamalarında dikkat edilmesi gereken bir diğer nokta öğretmenler tarafindan dönüt verilmesidir. Walberg ve Paik (1999), öğretmenlerin ev ödevlerine not vermesinin, ödevler üzerinde düzeltmeler yapmasının, öğrenci gelişimine dair yorumlarda bulunmasının ve sorular-çözümler üzerine bireysel ya da sınıf düzeyinde tartışmalar yürütülmesinin başarı üzerindeki etkisini üç katına çıkardığını ifade etmektedir. Öte yandan, Berberoğlu (2008) ders saatlerinin öğrenme faaliyetleri yerine ödev kontrolü için harcanmaması gerektiğini vurgulamaktadır. Bu anlamda verilen öneri, ödevlerin öğretmenler tarafından ders saatleri dışında kontrol edilmesi ve bireysel dönütlerin yazılı olarak iletilmesi şeklindedir; ancak ortak yanlışların düzeltilmesi adına ders içerisinde çalışmalar yürütülmelidir (Sullivan ve Sequare, 1996).

Alan yazında ev ödevleri ile ilgili olarak sıklıkla incelenen bir diğer durum, ev ödevlerine ayrılan zaman ve akademik başarı arasındaki ilişkiyi ortaya koymaya yöneliktir. Bazı araştırmacılar, ev ödevleri sebebiyle öğrencilerin akademik çalışmalarına harcadıkları zamanın arttığını; bu artışa paralel olarak da olgusal bilgilerin daha iyi anlaşıldığını ve öğrenme materyalinin daha iyi kavrandığını ve de eleştirel düşünme becerilerinin geliştiğini savunmaktadır (Marzano ve Pickering, 2007). Ödevler yoluyla öğrenmeleri üzerine uygulamalar yapma olanağı bulan öğrenciler, uzun vadede akademik anlamda olumlu sonuçlar alabilmektedir (Cooper, 2007). Bu nu destekler şekilde ders özelinde incelendiğinde, ilkokul düzeyindeki öğrencilerin okuduğunu anlama başarısını açıklamada en etkili değişknelerden biri olarak ödev yapma ve öğretmenlerin ödev verme sıklı̆̆ olduğunu gösteren çalışmalar da yer almaktadır (Kutlu, Yıldırım, Kumandaş ve Bilican, 2011). Bu yaklaşımda, bir pratik yapma olanağı olarak ev ödevlerinin öğrencilerin eleştirel düşünme ve bilgiyi işleme becerilerini geliștirmelerine, boş zamanlarında öğrenmeler gerçekleştirme yönünde desteklenmelerine, okula karşı olumlu tutum sergilemelerine ve de ders çalışma beceri ve alışkanlıklarını geliştirmelerine fayda sağlamaktadır. Ancak bunun tam tersi çalışmalar da mevcuttur. Cooper ve diğerleri (2006) tarafından yürütülen meta analiz çalışmasına göre ilkokul öğrencilerinin ev ödevleri için harcadıkları zaman ile akademik başarıları arasında neredeyse hiç ilişki yoktur. Ancak ev ödevine ayrılan zaman ile akademik başarı arasındaki ilişki ilkokuldan ortaokula; ortaokuldan liseye artı̧̧ göstermektedir (Bent-Hill, Boswell, Byers, Cohen, Cummings ve Leavitt, 1988; Cooper, Lindsay, Nye ve Greathouse, 1998; NCTM, 2008). Bu durumun ortaya çıkmasında, ilkokulda verilen ödevlerin çeşitli özellikleri belirleyici olabilir. Bunun yanı sıra ilkokul düzeyinde verilen ödevlerin, öğrencilerin daha çok duyuşsal özelliklerini hedef alması gerektiği ifade edilebilir. Bu bulgular, ev ödevine ne kadar zaman verildiğinden bağımsız olarak ev ödevinin içeriğinin ve amaca ne kadar hizmet ettiğinin belirlenmesinin daha anlamlı katkılar sağlayabileceği ifade edilebilir.

Ev ödevleri, pek çok ülkede olduğu gibi Türk Millî Eğitim Sistemi'nde de büyük bir role sahiptir. PISA 2012 verilerine göre, Türkiye en çok ödev veren beş ülkeden biridir. 1989 tarihli "Ortaokul ve Orta Öğretim Kurumları'ndaki Öğrencilerin Ders Dışı Eğitim ve Öğretim Faaliyetleri Hakkında Yönetmelik' inde ve 1989 tarihli TTB (Talim Terbiye Kurulu) 3101/5743 numaralı genelgede (23 Ekim 1989 tarihli ve 20321 sayll Resmi Gazete:12) yer alan maddelerden hareketle ev ödevleri için çizilen çerçeve genel olarak özetlenebilir. Her iki belgede de birinci kademede öğrenim görmekte olan öğrencilere kesinlikle ödev verilmemesi gerektiği, gerekli durumlarda 3. sınıfta günlük bir saati aşmamak, 4. ve 5. sınıfta iki saati geçmemek şartıyla verilebileceği vurgulanmıştır. Başka bir vurgulanan nokta ise öğrencilerin yaş, sınıf, bilgi düzeyleri ile aile ve çevre şartlarına göre ödev verilmesi gerekliliğidir. Son olarak da ödevlerin öğretmenler tarafından kontrol edilmesi gerektiği ifade edilmiştir. 2004-2005 eğitim öğretim yılında, okullardaki ev ödevi uygulamasında yeniliğe gidilmiştir. 27.8.2003 tarihli ve 25212 sayılı Millî Eğitim Bakanlı̆ğ İlköğretim Kurumları Yönetmeliği’nin 4. maddesi ve 35. maddesine göre, rutin ödevlere ek olarak proje, performans ve sınıf içi performans ödevlerine yer verilmeye başlanmıştır. Ancak uygulamada yaşanan aksaklıklar nedeniyle performans ödevleri yerini sınıf içi performans etkinliklerine bırakmıştır. Son gelişmelerden hareketle; ev ödevleri ilkokul birinci kademede, rutin olarak ifade edilebilecek, öğrencilere derste öğrenme etkinlikleri gerçekleştirilen hedef davranışları uygulama olanağı sunan alıştırmalar şeklinde yer bulmaktadır.

Uygulanmakta olan öğretim programının gereği olarak, 2017-2018 eğitim öğretim yılında ilkokul 4. sınıfa devam etmekte olan bir öğrenci haftada toplam otuz saat derse girmektedir (MEB, 2013). Öğrencilerin, geriye kalan kısıtlı zamanı ev ödevleri için olabildiğince etkili kullanmaları, ödevlerin hedeflerine hizmet etmeleri açısından önem taşımaktadır. Yeni uygulanan eğitim sisteminin gereği olarak bir sene sonra ortaokula başlayacak ve her ders için 
farklı bir öğretmenin verdiği ödevleri yapmak zorunda kalacak öğrencilerin dördüncü sınıf düzeyinde ev ödevlerine yönelik genel bir alışkanlık ve görüş edinmiş olmaları önemsenmektedir.

Alan yazında ilkokulda verilen ev ödevlerinin akademik başarı üzerinde etkisine yönelik bulguların farklılık göstermesi, Türkiye'deki ev ödevi uygulamalarının incelenmesi gerekliliğini doğurmaktadır. Ev ödevlerine yönelik öğretmen, öğrenci veya veli görüşlerini ortaya koyan çeşitli çalışmalar yer yürütülmüştür (Çetinkaya, 1992; Yapıc1, 1995; Akın, 1998; Hizmetçi ve İflazoğlu, 2006; Büyüktokatlı, 2009). Ancak öğrenci ve öğretmen görüşlerinin karşılaştırılmasıyla ev ödevi uygulamalarının bütüncül bir portresini oluşturacak nitelikte bir çalışmanın mevcut olmadığı gözlenmiştir. Bu noktada özellikle görüşleri dikkate alınması ve derinlemesine incelenmesi gereken paydaşlar, ödevi veren öğretmen ve ödevi yapan öğrencilerdir. İkinci olarak ödevlerin genel bir kavram olarak değil farklı türleri olarak incelendiği bir çalışmanın yürütülmesinin mevcut çelişkili bulguları gerekçelendirmede anlamlı bulgular sunabilecektir. Söz konusu iki paydaşın bakış açıları da ortaya konarak, ev ödevlerinin hizmet ettiği amaçlara göre ele alındığı bir çalışmanın yürütülmesi sıklıkla başvurulan ancak etkililiği tartışma konusu olan bu uygulamaların öğretmenlerin öngördüğü şekilde çalışıp çalışmadığının belirlenmesinde, ev ödevi uygulamalarında fark edilmeyen aksaklıkların belirlenmesine ve bu belirlemeler doğrultusunda ödev uygulamalarında gerekli değişikliklerin yapılmasına olanak verecektir. Bu anlamda, ev ödevlerine yönelik öğretmen görüşlerinin saptanması, dikkat edilmesi gereken noktaların pratik anlamda eğitim-öğretim sürecine nasıl aktarılabildiğini belirlemek açısından önemlidir. Tüm bu gerekçeler doğrultusunda, ev ödevi uygulamalarını Türkiye'deki diğer okullara benzer şekilde yürütmekte olan bir sınıf üzerinden farklı ödev türlerini ele alacak şekilde detaylı bir ev ödevi portresinin ortaya konmasının önemli olduğu söylenebilir. Bu sebeple, 4. sınıfta farklı amaçlarla verilen ev ödevlerinin öğretmen ve öğrenci görüşlerine dayandırılarak bir portresinin oluşturulması bir gereklilik olarak görülmüştür.

\subsection{Araştırmanın Amacı}

Çalışma kapsamında, ilkokul 4. sınıfta uygulanan ev ödevlerine yönelik öğrenci ve öğretmen görüşlerinin belirlenmesi amaçlanmıştır. Bu genel amaç doğrultusunda da aşağıdaki alt sorulara yanıt aranmıştır:

1- Öğretmen Görüşüne Yönelik Alt Sorular:

1.1. 4. sınıfta ev ödevleri nasıl uygulanmaktadır?

1.2. 4. sınıf öğretmeni ev ödevlerinin öğrencilere neler kazandıracağını öngörmektedir?

1.3. 4. sınıf öğretmeni ev ödevlerinde velinin rolünü nasıl değerlendirmektedir?

2- Öğrenci Görüşlerine Yönelik Alt Sorular:

2.1. 4. sinıf öğrencileri, ev ödevlerini nasıl betimlemektedir?

2.2. 4. sınıf öğrencileri, ev ödevlerinin kendilerine katkılarına yönelik görüşleri nelerdir?

2.3. 4. sınıf öğrencilerinin ev ödevlerinde velinin rolüne yönelik görüşleri nelerdir?

3- Öğretmen ve Öğrenci Ortak Görüşlerine Yönelik Alt Sorular:

3.1. Ev ödevlerinin sağladığı katkılara yönelik öğretmen ve öğrenci görüşleri benzerlik göstermekte midir?

3.2. Ev ödevlerindeki veli rolüne yönelik öğretmen ve öğrenci görüşleri benzerlik göstermekte midir?

\section{YÖNTEM}

\subsection{Araştırmanın modeli}

İlkokul 4. sınıf öğretmeninin ve öğrencilerinin verilen ev ödevlerine yönelik görüş ve beklentilerini saptamak ve bunların birbiri ile ne kadar örtüştüğünü belirleyerek ev ödevlerine yönelik bir betimleme portresi ortaya koymak amacıyla yürütülen bu çalışma, nitel araştırma temelinde desenlenmiştir. Çalışma, nitel araştırma desenlerinden bir durum çalışması ve durum çalışması türlerinden ise keşfedici durum çalışmasıdır. Durum çalışmalarında, genellikle belli bir olguya ilişkin bireysel algıların veya bakış açılarının ortaya çıkarılması ve yorumlanması amaçlanmaktadır (Yıldırım ve Şimşek, 2013). Yin (2003) ise daha spesifik olarak keşfedici durum çalışmalarının; bir müdahalenin değerlendirilmesinde, tek, açık ve net bir sonuç olmadığı durumlarda uygulandığını ifade etmektedir. Bu doğrultuda, söz konusu çalışmada belirlenen katılımcı öğretmen ve öğrenci görüşlerinden hareketle uygulanan çeşitli ev ödevlerinin durumunun ortaya konması hedeflenmiştir.

\subsection{Araştırmanın çalışma grubu}

Bu çalışma kapsamında verinin toplandığı okulun ve sınıfın saptanmasında da ulaşılabilirlik ve öğretmenin sıklıkla ev ödevlerine başvurması belirleyici olmuştur. Ayrıca bu sınıfın ev ödevlerinin, genel ev ödevi uygulamalarının tipik bir temsilcisi olması sebebiyle, bu sınıftan elde edilen bulguların anlamlı olacağı öngörülmüştür. Buna göre çalışma, 2016-2017 eğitim öğretim yılında bir ilkokuldaki dördüncü sınıf öğretmeni ve bu sınıfta öğrenim görmekte olan 25 öğrenci ile yürütülmüştür. Okul, Sivas ili merkez ilçesinde yer almaktadır ve bulunduğu konum 
itibariyle de üst sosyo-ekonomik düzeydeki öğrencileri barındırmaktadır. Katılımcı öğretmen, meslekte 35. yılını tamamlamıştır ve söz konusu grubun birinci sınıftan beri sınıf öğretmenliğini yapmaktadır. Öğretmen, çalışma için gönüllü olmuştur. Ayrıca öğretmenin ifadelerine ve süreç öncesi gözlemlere bağlı olarak, sınıf-içi uygulamaları öğretmen kılavuzunda yer alan önerileri takip ederek yapılandırması, ödevi tercihlerini sınıfın ihtiyaçlarına bağlı olarak şekillendirmesi ve bu konuda çeşitlilik sağlamaya dikkat etmesi katılımcı olarak seçilmesinde belirleyici olmuştur. Böylelikle, aynı grup üzerinde çeşitli ödev türlerinin yansımalarının gözlenmesine olanak sağlayabilmiştir.

\subsection{Veri toplama araçları ve süreci}

Çalışma kapsamında, öğrencilerin ve öğretmenlerinin görüşlerini belirlemek amacıyla iki standartlaştırılmış görüşme sorularından yararlanılmıştır (Ekler). Öğretmen ve öğrencilere yöneltilecek iki grup sorunun hazırlanmasında alan yazındaki mevcut çalışmalar ve araştırmanın amaçları dikkate alınmıştır. Standartlaştırılmış görüşmelerde hazırlanmış sorular sırası ya da ifade ediliş biçimi değiştirilmeden ve ekleme yapılmadan katılımcılara yöneltilmektedir (Berg ve Lune, 2011). Standartlaştırılmış görüşmelerde, tüm katılımcılara aynı uyarıcıların sunulması ile alınan yanıtların karşılaştırılabilirliğinin artırılması hedeflenmektedir. Görüşme sırasında sorularda değişiklik yapılmamasından doğan bu standartlaştırmanın sağladığı avantajdan yararlanılabilmesi için elde edilen veriye sorulardan kaynaklı karışacak hata payının en aza indirgenmesi özellikle önem taşımaktadır. Bu sebeple soruların olabildiğince kapsamlı olacak şekilde hazırlanmasına dikkat edilmiştir. $\mathrm{Bu}$ doğrultuda, çalışmanın iç geçerliğini sağlamak için uygulama öncesinde hazırlanan sorulara yönelik uzman görüşü başvurulmuştur. Bu amaçla üç ölçme ve değerlendirme alanında akademisyen ve bir sınıf öğretmeni olmak üzere dört konu uzmanının görüşleri alınmış, ardından çalışmaya katılan öğretmenden farklı bir öğretmen soruları öğrencilerin gelişim düzeyleri ve çalışmanın amacı dikkate alınarak anlaşılırlık ve okunabilirlik yönünden değerlendirmiştir. Uzman görüşleri doğrultusunda sorularda gerekli düzeltmeler yapılmış ve sorulara nihaî şekli verilmiştir. Öğrencilerin yaş düzeyi dikkate alınarak, ilgi çekiciliğini artırmak amacıyla yazılı yanıtlamaları istenen görüş formunda görsel unsurlar kullanılmıştır. Formlar üzerinde katılımcıları bilgilendirmeye yönelik olarak gerekli açıklamalara yer verilmiş; ayrıca öğrenciler yanıtlamadan önce form hakkında sözlü olarak bilgilendirilmiştir.

Çalışmanın veri toplama işlemleri, belirlenmiş “Trafik Güvenliği’” dersi kapsamında öğretmenin verdiği ödevlere yönelik olarak üç aşamada gerçekleştirilmiştir. Trafik Güvenliği dersinin öğretim programında "Özellikle araştırma içerikli kazanımlara yönelik öğrencilere verilen görevlerde, öğrencilerin araştırma sonuçlarını afiş, poster, pano, broşür, gazete, tablo, grafik vb. materyaller ile sunu yapma gibi etkinliklerle desteklemelerine özen gösterilmelidir." ifadesi ders uygulamaları sırasında dikkate alınması gereken noktalardan biri olarak belirtilmiştir (MEB, 2018). Bu durumun çalışmanın amacına uygun olarak çeşitli ödevler verilmesine olanak sağlayacağı göz önünde bulundurulmuş ve çalışmanın Trafik Güvenliği dersi üzerinden yürütülmesinde etkili olmuştur. Ayrıca, "Trafikte kendisinin ve başkalarının hayatının önemli olduğunu fark eder.", "Trafikle ilgili temel kavramları açıklar." ve "Trafikte sorumlu, saygılı ve sabırlı olmanın gerekliliğini sorgular." hedef davranışları yer almaktadır. Söz konusu hedef davranışlar, öğrencilerin eleştirel düşünmelerini ve farkındalık geliştirmelerini gerektirmektedir. $\mathrm{Bu}$ davranışların geliştirilmesi ve değerlendirilmesinde ise çeşitli öğretim faaliyetleri ve ödev uygulamaları için elverişlidir. Bu durumlar dikkate alınarak söz konusu çalışmanın Trafik Güvenliği dersi kapsamında yürütülmesine karar verilmiştir.

Öğretmen ders kapsamında öğrencilere üç ödev vermiştir. İlkinde öğrencilerden gazetelerden trafik kazaları haberlerini kesip getirmelerini istemiştir. İkinci aşamada, kestikleri haberlerle ilgili kuralları vurgulayan bir metin yazmalarını istemiş ve son aşamada da trafik kuralları konulu bir testi yanıtlamalarını istemiştir. Bu üç ödev alan yazında belirlenen ödev sınıflamalarının (Cooper, 2007) tipik birer örneği olarak paydaşların görüşlerini belirlemek için anlamlı oldukları öngörülmüştür.

Araştırmacı, her bir ödevin teslim edilişinin ardından öğrencilerden hazırlanmış görüş formunu doldurmaları istemiştir. Öğrenciler, her bir ödevin ardından o ödeve yönelik görüşlerini yansıtacak şekilde soruları yanıtlamışlardır. Öğretmen görüşlerinin saptanmasında ise yüz yüze yapılan yarı yapılandırılmış görüşme tekniğinden yararlanılmıştır. Görüşme, "Önceden belirlenmiş ve ciddi bir amaç için yapılan, soru sorma ve yanıtlama tarzına dayalı karşılıklı ve etkileşimli bir iletişim sürecidir.” (Stewart ve Cash, 1985). Bu yaklaşımın temelinde görüşmelerin araştırmacıya aldığı yanıtlar doğrultusunda yeni sorular sorabilme ve gerekli durumlarda bazı soruları yok sayabilme olanağı veren esnek süreçler olması yatmaktadır. Öğrencilere benzer şekilde her ödevin tamamlanışının ardından öğretmenin o ödeve yönelik görüşleri belirlenmiştir. Tüm konuşmalar ses kaydına alınmış ve araştırmacı tarafından görüşme sırasında notlar alınmıştır.

\subsection{Verilerin analizi}

Çalışmanın bulguları üzerinden içerik analizi gerçekleştirilmiştir. Betimsel analizde, "elde edilen veriler daha önceden belirlenen temalara göre özetlenmekte ve yorumlanmaktadır” (Yıldırım ve Şimşek, 2013; 256). Y1ldırım 
ve Şimşek söz konusu analizin aşamalarını betimsel analiz için çerçevenin oluşturulması, tematik çerçeveye göre verilerin işlenmesi, bulguların tanımlanması ve bulguların yorumlanması aşamaları ile açıklamaktadır. Daha detaylı bir yaklaşımla nitel araştırmaların sayısallaştırılması işlemini Weber (1990) ise tema, kod kategori hiyerarşisini vurgulayarak, önce analiz biriminin belirlendiğini, daha sonra da tema veya kategorilerin açıkça tanımlandığını ifade etmektedir. Sonraki aşamada örnek veri setinde belirlenen tema, kod ve kategorilerin denenmekte ve gerekli düzeltmelerin ardından tüm veri setinde kodlamanın gerçekleştirildiği ve yüzdelerin hesaplanması işleminin gerçekleştirildiğini belirtmektedir.

Bu çalışma kapsamında da görüşme formalarından elde edilen olan görüşme dökümleri incelenmiştir. Öncelikle görüşme dökümlerinin tümü incelenmiş ve alan yazındaki mevcut çalışmalardaki yaklaşımlar da dikkate alınarak bir çerçeve oluşturulmuştur. Oluşturulan çerçeveye bağlı olarak, döküm tematik çerçeveye göre tekrar incelenmiştir. Her bir öğrenci yanıtında yer alan sözcükler analiz birimi olarak ele alınmış ve çerçeve kapsamında kod olarak tanımlanarak birbiri ile ilişkilendirilerek gruplandırılmıştır. Son aşamada ise yapılan gruplandırmalara bağlı olarak yüzde/Sayı hesaplaması yapılarak doğrudan alıntılarla desteklenmiş ve yorumlanmıştır.

Öğretmenle yapılan sözlü görüşmeler öncesinde de gerekli açıklamalarda bulunulmuş ve görüşmelerin doğal bir sohbet ortamı içerisinden gerçekleştirilmesi sağlanmıştır. Öğretmenle yapılan her bir görüşme yaklaşık 15 dakika sürmüştür. İç geçerliğe yönelik tehdidi azaltmak için veri öğretmen ve öğrenci olmak üzere iki farklı kaynaktan toplanmıştır. İç geçerliği artırmaya yönelik olarak uygulanan ve çeşitleme olarak adlandırılan bu işlem Patton (1999) tarafından "Nitel çalışmalarda, konuya yönelik kavranabilir bir anlayış sunmak amacıyla birden çok yöntem ve veri kaynağının kullanılması” olarak tanımlanmaktadır. Çalışmanın dış geçerliğinin sağlanması için de araştırma modeli, katılımcılar, veri toplama araçları, verilerin toplanması, verilerin analizi ve bulguların nasıl düzenlendiği ayrıntılı olarak betimlenmiştir. Bunun yanı sıra çalışmanın gerçekleştirileceği sınıfın belirlenmesinde amaca uygun olarak anlamlı katkılar sağlayacak özelliklere sahip olmasına dikkat edilmiştir.

Çalışmanın güvenirliğine yönelik olarak bulguların yorumlardan arındırılmış olarak olduğu gibi yansıtılmaya çalışılması; öğretmenle yapılan görüşmeler esnasında ses kaydı alınması ve ses kaydının deşifre edilerek çözümlenmesi ile veri kaybının önüne geçilmesi hedeflenmiştir. Öğrencilerin görüşleri ise Çalışmanın içgüvenirliğini artırmaya yönelik olarak, nitel araştırma ve nitel veri analizi konusunda çalışmalar yürütmüş bir ölçme ve değerlendirme uzmanından seçkisiz olarak belirlenmiş sekiz öğrencinin her üç görüş formundaki ifadeleri ve öğretmenin ifadelerini kodlaması istenmiştir. Biri araştırmacı diğeri ölçme ve değerlendirme uzman olmak üzere iki kodlayıcı tarafından kodlanan verilerin tutarlığı uyuşma yüzdesi indeksi ile incelenmiştir:

$$
r=\frac{\text { Görüş Birliği Să̆lanan İfade Sayısı }}{\text { Görüş Birliğ } i \text { Sağlanan İfadeSayısı + Görüş Ayrılığı Olan İfade Sayısı }}
$$

formülü kullanılarak hesaplanmıştır (Miles ve Huberman, 1994). Öğretmen görüşlerine yönelik kodlayıcılar arası güvenirlik değeri \%95 iken öğrenciler için bu değer \%94 olarak hesaplanmıştır. Bu kabul edilebilir değerler elde edilmiştir ancak uzmanın önerilerine bağlı olarak kodların ait olduğu kategorilerin belirlenmesinde daha tutarlı tutarlı sonuçlar elde etmeye yönelik olarak kategoriler daha kapsayıcı ifadelerle tanımlanmıştır.

\section{BULGULAR}

\subsection{Sınıftaki Ev Ödevi Rutini ve Ev Ödevlerine Yönelik Öğretmen Görüşleri}

1.1.ve 1.2. alt araştırma sorularına yönelik olarak çeşitli sorular yöneltilmiştir (Ek.2). Öğretmen ödevleri ikişer aylık sürece yayılan üniteler çerçevesinde uyguladığını ifade etmiştir. Buna bağlı olarak ünite başlangıcında, ünite süresince ve ünite sonunda ödevler verilmektedir. Öğretmen, ödevlerin ünite kazanımlarına yönelik olmasının dikkate alınan en önemli nokta olduğunu belirtmiştir; ödevin amacına hizmet etmesinin önemsediği noktalardan biri olduğunu vurgulamıştır. Öğrencilerin yetkinlik ve yeterlilik düzeylerinin üzerinde ödevlerin verilmemesine de itina ettiğini dile getirmiştir:

\footnotetext{
"Öğrencilerden sanat eseri beklemiyorum tabiı̂ ki; kendisinin yapabileceği şeyler. Aile desteklediğinde mükemmele yakın şeyler geliyor ama çocuklar yaratıcılıklarını kattığında daha hoş durumlar ortaya çıkıyor. Bunu desteklediğimi vurguluyorum sınıf içinde, "Çok güzel ama annen yardımcı olmuş galiba, kendin yapsan daha güzel olurdu. " gibi ifadeler kullaniyorum."
}

Öğretmen, öğrencinin katkısını gerektirmeyen ödevlerden kaçındığını; bu sebeple öğrencileri, özümsemeden sadece internetten çıktı almaya yönlendirecek ödevlerden olabildiğince uzak durduğunu dile getirmiştir.

Öğretmen, öğrencilere sağlanan dönütler için farklı ödevlerde farklı yöntemler izlemektedir. Buna göre öğretmen, günlük ödevlerin kontrolünü sıra arkadaşlarının birbirlerinin kâğıtlarını incelemesiyle gerçekleştirdiğini ifade 
etmiştir. Buna göre ortak yanlış sorular, sınıfta yanıtlanmakta; gerektiğinde öğrenciler bazı sorularda öğretmenden bireysel yardım almaktadırlar. Diğer ödevlerin kontrolünü ise öğretmen kendisi gerçekleştirmektedir.

Sınıf öğretmeninin verdiği ödevler derse hazırlık, tekrar ve değerlendirme olmak üzere alan yazında yer alan üç eğitsel amaca hizmet etmektedir. Bu amaçlara bağlı olarak öğretmen kendi ifadesiyle "araştırma", "üretme” ve "test çözme" ödevleri vermektedir:

“...Her gün işlenen konu ile ilgili testleri ödev olarak veriyorum... Tekrar için verilen testlerde sınıfin eksikleri hemen ortaya çıkıyor... Bunun dışında her ünitenin başında ve sonunda araştırma ve üretme ödevi veriyorum... Araştırma ödevlerini konuya hazırlanmaları için veriyorum; temelleri olduğunda bilerek dinliyorlar. Ders esnasında benden farklı bir şey söylemek onlara iyi hissettiriyor. Üretme ödevlerini de düşünceleri ifade edebilsinler; duygularını katabilsinler diye veriyorum."

Eğitsel amaçların yanı sıra, ödevlerin öğrencilerde sorumluluk bilincinin geliştirilmesi ve araştırma becerilerin edinilmesi gibi eğitsel olmayan amaçlara da hizmet ettiği öğretmen tarafindan belirtilmiştir.

“Ev ödevi sadece ögrenme ile ilgili değil. Çocukların sorumluluk almalarını da să̆lıyor. Bir de kendisiyle birebir kalıp bilgisini kontrol edebiliyor; sınava ne kadar hazır olduğunu belirliyor.”

Öğretmen özel olarak çalışma kapsamında verdiği ödevler aracılığı ile kazandırmayı hedeflediği davranışları da genel amaçlar kapsamında tasarladığını ifade etmiştir. Öncelikle öğretmen, gazetelerden trafik kazası haberi kesme ödevi (Ödev I) ile öğrencilerde merak uyandırmanın ve farkındalık kazandırmanın amaçlandığını dile getirmiştir. Öğretmen, kestikleri haberlere yönelik görüşlerini yansitan bir kompozisyon yazma ödevi (Ödev II) ile de benzer şekilde kendilerini ifade etme olanağı bulmalarını sağlamayı ve son olarak test çözmeleri istenen ödevde (Ödev III) ile ise öğrencilerin konuyu pekiştirmesinin desteklenmesini hedeflediğini belirtmiştir:
"Öğrencilerden gazetelerden haberler kesmelerini istedim çünkü konuya yönelik merak uyandırmak, farkindalık kazandırmak istiyorum. Kazaların sebepler anlatıliyor ama resimlerle ve haberlerle durumun ciddiyetine vardırmak daha kolay. Kazalar nelere mâl oluyor? Kazaların sebebi ne? Trafik kurallart neden gerekli?...
“Bu ikinci ödevi düşüncelerini ifade edebilsinler diye verdim; kazanımlarını yazıya döksünler diye kısa paragraflar yazdırlyorum...”
“Test çözme ödevini eksiklerini ortaya çıkarmak için verdim. Pekiştirme amaçlı olarak.”

1.3. alt araştırma sorusunu yanıt bulmak amacıyla, velinin ev ödevlerindeki rolünü belirlemeye yönelik öğretmene sorular yöneltilmiştir. Öğretmen, velinin ev ödevi konusunda rolünü ağırlıklı olarak veli-öğrenci ilişkileri açısından değerlendirmiştir:

"Aileleriyle yapabildikleri ödevden mutlu oluyorlar, önemli hissediyorlar kendilerini. Ailelerinin onlara zaman ayırması hoşlarına gidiyor. Özellikle araştırma yapmaları gereken ödevlerde aileleriyle birlikte çalışmak ilişkileri açısından faydall. Böylelikle yükleri de hafifliyor.”

“...Konuyu öğretmenden başka birinin ăgzından dinleyerek farklı noktaları keşfedebiliyorlar...”

\section{2. Öğrencilerin Ev Ödevlerine Yönelik Genel Görüşleri}

2.1 numaralı alt araştırma sorusuna yanıt bulmak amacıyla, öğrencilerden, ev ödevlerine yönelik genel algıları belirlenmiştir. Bu doğrultuda öğrencilerden "Ev ödevleri ..... gibidir çünkü....." ifadesindeki boşlukları doldurmaları istenmiştir. Öğrencilerin her üç ev ödevine yönelik olarak yaptıkların betimlemeler aşağıdaki tabloda görüldüğü gibidir: 
Tablo 1.

Ögrencilerin Verilen $\ddot{U} c ̧$ Ev Ödeve Yönelik Betimlemeleri

\begin{tabular}{|c|c|c|c|c|c|c|}
\hline \multirow[t]{2}{*}{ Kategori } & \multicolumn{2}{|c|}{$\begin{array}{c}\text { Ödev I } \\
\text { Kaza Fotoğrafı Bulma }\end{array}$} & \multicolumn{2}{|c|}{$\begin{array}{c}\text { Ödev II } \\
\text { Kaza ile İlgili } \\
\text { Kompozisyon Yazma }\end{array}$} & \multicolumn{2}{|c|}{$\begin{array}{c}\text { Ödev III } \\
\text { Test Çözme }\end{array}$} \\
\hline & Sayı & Yüzde & Sayı & Yüzde & Sayı & Yüzde \\
\hline Kolay/zor & 6 & 24 & 5 & 20 & 13 & 52 \\
\hline $\begin{array}{l}\text { Ĕ̆lenceli// Keyifli/Güzel } \\
\text { /İyi }\end{array}$ & 6 & 24 & 7 & 28 & 3 & 12 \\
\hline $\begin{array}{l}\text { Öğretici/Faydalı } \\
\text { /Bilgilendirici }\end{array}$ & 4 & 16 & 4 & 16 & 7 & 28 \\
\hline Üzücü/İbret Verici & 12 & 48 & 8 & 32 & 4 & 16 \\
\hline Araştırma & 1 & 4 & - & - & - & - \\
\hline
\end{tabular}

Tablo 1'de görüldüğü gibi öğrencilerin her üç ödeve yönelik betimlemeleri, kolay/zor; eğlenceli/keyifli/güzel/iyi; öğretici/faydalı/bilgilendirici ve üzücü/ibret verici olmak üzere beş başlık altında toplanabilir. Öğrenciler, Ödev III'ü öncelikle zorluk düzeyine; ikinci olarak da öğretici/faydalı/bilgilendirici olma durumuna göre betimlemişlerdir. Üçüncü ve dördüncü düzeyde de üzücü/ibret verici olma ve eğlenceli/keyifli/güzel/iyi olma betimlemelerini kullanmışlardır. Ödev II için sıralama üzücü/ibret verici; eğlenceli/keyifli/güzel/iyi; kolay/zor ve öğretici/faydalı/bilgilendirici olma şeklinde gerçekleşmiştir. Ödev I için betimlemeleri; üzücü/ibret verici, kolay/zor; eğlenceli/keyifli/ güzel iyi; öğretici/faydalı/ bilgilendirici ve araştırma olarak sıralanmıştır.

Öğrenciler, Ödev III'ü kolaylık/zorluk açısından betimleme eğilimi göstermiştir. Buna bağlı olarak, bu ödeve yönelik görüşlerini dile getirirken 5 öğrenci sınava hazırlanma; 7 öğrenci de bilgilerini pekiştirme ifadelerini kullanmışlardır. $\mathrm{Bu}$ anlamda öğrencilerin soru çözmeleri gereken ödevleri sonuca ulaşıp ulaşmama açısından değerlendirdikleri ifade edilebilir. Ödev I ve Ödev II için öğrenciler, zorluk/kolaylıktan ziyade eğlenceli ya da üzücü gibi kendilerindeki duygusal yansımalarına yönelik betimlemek eğiliminde görüş belirtmişlerdir. Bundan hareketle, öğrencilerin bu ödevde daha çok sürece odaklanarak değerlendirdikleri görülmüştür. Bu bilgiler, ev ödevlerinin kendilerine katkılarına yönelik öğrenci görüşleri ile de desteklenmiştir.

2.2. alt araştırma sorusuna yanıt bulmak amacıyla, öğrencilerin ev ödevlerinin sağladığı katkılara yönelik görüşleri belirlenmiştir. Buna göre öğrencilerin üç ödev için de sağlanan katkılara yönelik görüşlerini bilgi düzeyinde kazanımları, farkındalık anlamında katkıları ve farklı beceri türlerine yönelik katkıları olmak üzere üç kategori katkıları incelemek mümkündür. Her üç ödev için üç kategoriye ait olduğu belirlenen katkıları aşağıdaki tablodaki gibidir:

Tablo 2

Ev Ödevlerinin Să̆ladı̆̆ı Katkılara Yönelik Görüşleri ve Bu Görüşlere Dă̆glımları

\begin{tabular}{lcccccc}
\hline \multicolumn{1}{c}{ Kategori } & \multicolumn{2}{c}{$\begin{array}{c}\text { Ödev I } \\
\text { Kaza Fotoğrafı Bulma }\end{array}$} & $\begin{array}{c}\text { Kaza ile ilgili Kompozisyon } \\
\text { Yazma }\end{array}$ & \multicolumn{2}{c}{$\begin{array}{c}\text { Ödev III } \\
\text { Test Çözme }\end{array}$} \\
\cline { 2 - 8 } & Sayı & Yüzde & Sayı & Yüzde & Sayı & Yüzde \\
\hline $\begin{array}{l}\text { Bilgi Düzeyinde Katkılar } \\
\text { Farkındalık Anlamında }\end{array}$ & 7 & 28 & 5 & 20 & 19 & 76 \\
$\begin{array}{l}\text { Katkılar } \\
\text { Farklı Beceri Türleri }\end{array}$ & 8 & 40 & 11 & 44 & 6 & 24 \\
\begin{tabular}{l} 
Anlamında Katkılar \\
\hline
\end{tabular} & 32 & 6 & 24 & - & - \\
\hline
\end{tabular}

Öğrenciler, verilen ödevlerin trafik kurallarını öğrenmelerini sağladığını belirtmişlerdir. Her üç ödev için de "Trafik kurallarını öğretti." genel ifadesinin yanı sıra "Emniyet kemeri takma”, “Aşırı hız yapmama”, "Alkollü araç kullanmama", "Trafikte dikkatli olma" gibi özel bilgilere değinmişlerdir. Ödev II için "Trafiği daha iyi öğrendim.” ve Ödev III için “Trafik kurallarını öğretti.” ifadelerini kullanmışlardır.

Farkındalık kazanma anlamında, trafik kazalarının sıklığını fark ettiklerini, kuralların öneminin ve gerekliliğinin anlaşıldığının vurgulandığı ifadeler gözlenmiştir. Ödev I için "Ödevden sonra trafik kurallarına uymamız gerektiğini düşünüyorum.”, “Trafik kurallarının hayatî önemini ve hayat kurtardığını gördüm.”, "Hızın ve dikkatsizliğin nelere yol açtığını görüp öğrenmiş oldum.”, Ödev II için “Ölenlerin, yaralananların ailelerinin durumunu daha iyi kavradım.” ve Ödev III için “Trafik kazaları hakkında farkındalık kazandım.” ifadelerini kullanmışlardır.

Öğrenciler farklı beceriler edinmesine yönelik olarak Ödev I ve Ödev II için araştırma gerektirdiğini vurgulamışlardır. Buna yönelik Ödev I için "Ödev için araştırma yaptım.” ve Ödev II için "Ben araştırma yapmayı 
çok severim. Bu ödev için de araştırma yaptım.”. Ayrıca Ödev I "Gazetelerden küpür kesmek ellerimi çalıştırdı." ifadesi motor becerilerin gelişimine etkisine yönelik olarak değerlendirilmiştir.

2.3. alt araştırma sorusunun gereği olarak, velinin ev ödevindeki rolüne yönelik öğrenci görüşlerini tespit etmek amaciyla öğrencilere sorular yöneltilmiştir. 2 öğrenci Ödev I için, 3 öğrenci Ödev II ve 5 öğrenci Ödev III için yardım almadıklarını belirtmiş̧leridir. Ödev III için ise 8 öğrenci yardım almamıştır. Yardım almamalarının gerekçesini ödevin kolay olması ve kendi başlarına yapabilmeleri ile ifade etmektedir. Yardım alan öğrencilerin ise velinin ev ödevlerindeki rolü, ödevden emin olma ve iyi hissettirme olmak üzere iki kategori altında incelenebilir:

Tablo 3.

Verilen Ü̧̧ Ev Ödevinde Velinin Rolüne Yönelik Öğrenci Görüşleri

\begin{tabular}{|c|c|c|c|c|c|c|c|}
\hline \multirow{2}{*}{\multicolumn{2}{|c|}{ Kategori }} & \multicolumn{2}{|c|}{$\begin{array}{c}\text { Ödev I } \\
\text { Kaza Fotoğrafı Bulma }\end{array}$} & \multicolumn{2}{|c|}{$\begin{array}{c}\text { Ödev II } \\
\text { Kaza ile ilgili } \\
\text { Kompozisyon Yazma } \\
\end{array}$} & \multicolumn{2}{|c|}{$\begin{array}{l}\text { Ödev III } \\
\text { Test Çözme }\end{array}$} \\
\hline & & Sayı & Yüzde & Sayı & Yüzde & Sayı & Yüzde \\
\hline \multirow{2}{*}{ Yardım alanlar } & $\begin{array}{l}\text { Ödevden Emin } \\
\text { Olma }\end{array}$ & 6 & 24 & 7 & 28 & 5 & 20 \\
\hline & $\begin{array}{l}\text { Önemsenme/Mutl } \\
\text { uluk }\end{array}$ & 16 & 64 & 13 & 52 & 10 & 40 \\
\hline \multirow{2}{*}{$\begin{array}{l}\text { Yardım } \\
\text { Almayanlar }\end{array}$} & Kendine Güven & 2 & 8 & 3 & 12 & 5 & 20 \\
\hline & Kötü Hissetme & 1 & 4 & - & - & - & - \\
\hline
\end{tabular}

Çizelge incelendiğinde, öğrencilerin her üç ödevde de ailelerinin yardımcı olması onlara iyi hissettirdiği görülmektedir. Öğrencilerin kullandıkları ifadelerden bazıları; Ödev I için " Dedemden yardım aldım. Beraber gazetelerden resim bulmaya çalıştık. Bana yardımcı olduğu için mutlu oldum.", Ödev II için "Yaparken annemden yardım almak, bana ilgi gösterdiğini görmek beni önemsediğini hissettirdi." ve Ödev 3 için "Yaparken annemden yardım almak bana ilgi gösterdiğini ve benim kadar bu konuyu önemsediğini gösterdiğini hissettirdi." şeklindedir. Öğrenciler, her üç ödev için de yardım almanın ödevden emin olmalarını sağladığını belirtmiş̧tir. Buna yönelik öğrencilerin ifadeleri Ödev I için "Evet yardım aldım. Bu bana güven duygusu verdi. Kendimden emin oldum.", Ödev II için "Annemden yardım aldım. Bu bana yanlış yapmadığımı hissettirdi." ve Ödev III için "Babamdan yardım aldım. Ben yaptım, o kontrol etti.”. Öğrencilerin kategorilere dağılımları incelendiğinde, öğrencilerin genel olarak ödev yaparken velilerinin yardımcı olmasından memnun oldukları gözlenmiştir.

\subsection{Ev Ödevlerinin Sağladığı Katkılara Yönelik Öğretmen ve Öğrenci Görüşleri Benzerlik ve Farklılıkları}

3.1. numaralı araştırma sorusuna yanıt olarak, öğretmenin ödevleri verirken sahip olduğu genel beklentilerin öğrencilerde karşıllığını bulduğu söylenebilir. Aşağıdaki şekilde, öğrencilerin ev ödevine yönelik betimlemelerine dağılımları ve öğretmeninin ödevden beklentileri görselleştirilmiştir:

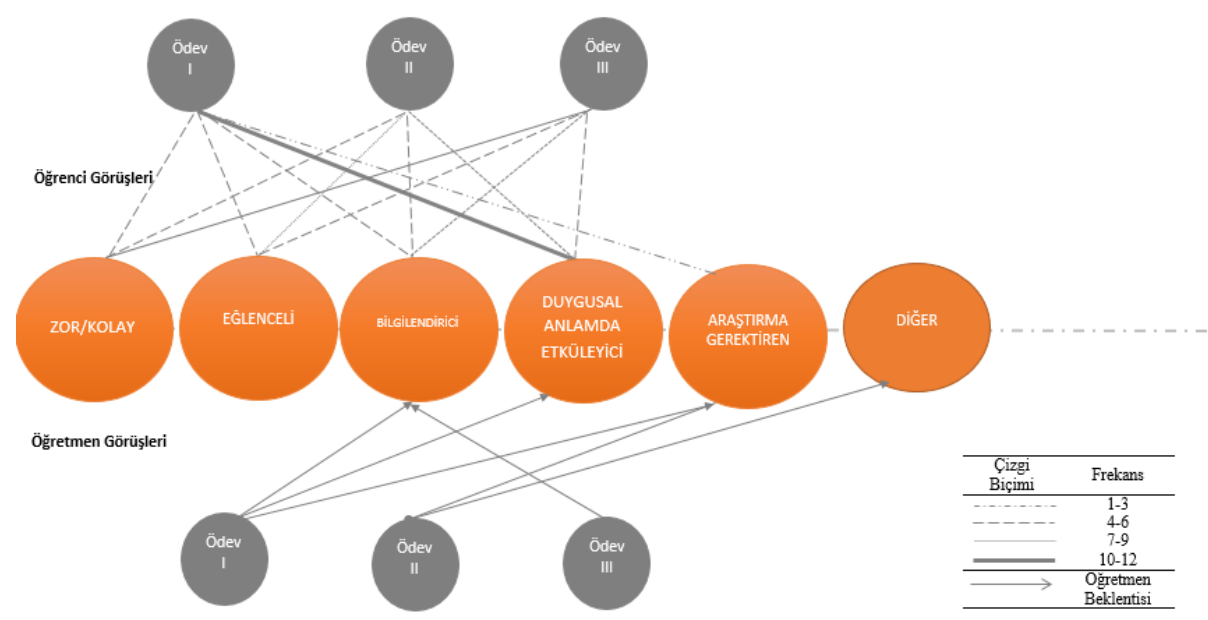

Şekil. Öğretmenin ve Öğrencilerin Ödeve Yönelik Genel Görüşlerinin Dağllımları

Şekil incelendiğinde, genel anlamda her iki paydaşın da ifadelerinde ev ödevlerinin öğrencilerin bilgi birikimlerini artırmak, farkındalık kazandırmak ve farklı beceriler geliştirmek anlamında katkı sağladığını vurguladıkları görülmektedir. Öğretmenin her ödevden beklentisi olan temel katkılar, öğrenci ifadelerinin de yoğunlaştı̆̆ noktalardır. Detaylı incelenecek olursa, ilk ödev için öğrencilerin ağılıkla öğretmenin yeni bir konuya başlamadan 
önce dikkat çekme ve farkındalık kazandırma amacını doğruladıkları görülmektedir. Benzer şekilde öğrenciler, bu ödevden sağladıkları katkıları dile getirirken trafik kazası haberlerini araştırmanın trafik kurallarının gerekliliğini fark etmelerine sağladığı katkıyı yansıtan ifadeler kullanmışlardır. Buna bağlı olarak öğrenciler ağırlıkla bu ödeve yönelik duygusal tepkilerini dile getirmişlerdir. Bu anlamda, öğretmen beklentilerinin öğrencilerde karşılığını bulduğu söylenebilir. Ancak ikinci ödev incelendiğinde öğrencilerin çoğunun bu ödevi eğlenceli bulma eğiliminde olduğu görülmektedir. Öğretmenin ise bu ödevden beklentisi, yaratıcılıklarını ortaya koymaya ve öğrendiklerini kendi sözcükleri ile ifade etmeye yönelik beklentisinin öğrencilerde karşılık bulmadığı gözlenmiştir çünkü öğrenciler kendi görüşlerini yansıtma, ürün ortaya koyma gibi ifadeler kullanmamışlardır. Bunun temelinde öğrencilerin kompozisyon ödevinde haberi özetleme yoluna gitmiş olmaları yatıyor olabilir. Ödev III incelendiğinde ise öğretmenin ve öğrencilerin "Bilgilendirici" olması yönünde ortak görüş bildirdikleri görülmektedir. Bu ödeve yönelik öğretmen beklentileri, ders tekrarı olması yönündeyken öğrenciler daha çok sınava hazırlık yapma olanağı sunduğunu vurgulamaktadırlar. Genel olarak öğrenciler, tüm ödevlerin bilgi birikimlerine katkı sağladığını ifade etmişlerdir. Ancak ifadeleri daha detaylı incelendiğinde, öğrencilerin üçüncü ödev için rekabet, kazanma ve başarı odaklı yaklaştıkları görülmüştür. Bireylerin motivasyonlarının yüksek olması olumlu bir durum olmakla birlikte, diğer iki ödevin öğrencilere, öğrendiklerini anlamlandırma ve bilgilerin gerekliliklerinin farkına varma noktasında katkı sağladığı görülmektedir. Bu durumun bir yansıması olarak da ilk iki ödeve yönelik görüşlerini belirtirken kurallardan birebir örneklere yer vermiş ancak üçüncü ödeve yalnızca genel hatları ile öğrenmek ve başarılı olmak açısından yaklaşmışlardır. Bu bağlamda, sadece soru çözmeyi gerektiren ödevlerin araştırma ve yeni ürün ortaya koymayı gerektiren ödevlerle desteklenmesi, bireylerin öğrenmeye isteklerini artırma yönünden olumlu etkiye sahip olacaktır.

3.2. alt araştırma sorusuna yanıt bulmak amacıyla, her iki paydaşın ev ödevi uygulamalarında rollerine yönelik görüşleri karşılaştırılmıştır. Bu doğrultuda, öğretmen genel olarak ailelerinden yardım almanın öğrencilerde olumlu duygular uyandırdığını ifade etmiştir. Öğrencilerin ifadeleri incelendiğinde de benzer şekilde kendilerine olumlu hissettirdiği gözlenmiştir. Ancak öğretmen, farklı kaynaklardan konuyu dinlemenin öğrencilere farklı bilgiler kazandırdığını ifade etmesine rağmen öğrencilerde ev ödevlerinin böyle bir yansıması olmadığı gözlenmiştir.

\section{TARTIŞMA ve SONUÇ}

Ev ödevleri, hem eğitsel hem de eğitsel olmayan pek çok amaca yönelik olarak sıklıkla başvurulan uygulamalardır. $\mathrm{Bu}$ çalışma kapsamında da bir dördüncü sınıf öğretmeninin ve öğrencilerinin görüşlerine başvurularak bir ev ödevi portresi çıkarılmıştır. Öğretmenin ev ödevlerini verirken sahip olduğu öngörülerin öğrencilerde karşılığını bulup bulmadığı ortaya konmaya çalışılmıştır.

Öğretmen, belli bir ödev rutini olduğunu ifade etmiştir. Buna göre öğretmenin Cooper'ın (2007) sınıflamasına benzer şekilde öğretmen, ödevleri eğitsel amaçlar doğrultusunda konuya hazırlanma, konuyu pekiştirme ve değerlendirme; eğitsel olmayan amaçlar doğrultusunda ise araştırma yapma, farkındalık kazanma ve sorumluluk bilinci geliştirme gibi hedef davranışların geliştirilmesine yönelik vermektedir. Araştırmaya katılan öğretmenin ev ödevine bakış açısı genel olarak olumludur. Cooper (2003), ev ödevlerini okul-öğrenci-veli üçgenindeki bir etkileşim aracı olduğunu belirtmektedir. Bu sebeple, katılımcı öğretmenin veli rolüne yönelik beklentisinin alan yazından farklılaşmadığı belirtilebilir. Benzer şekilde, Epstein ve Becker (1982), ödevlere öğrencilerin özyeterlilik, sorumluluk bilinci, zaman yönetimi gibi beceri ve özelliklerinin gelişimlerini desteklemeye yönelik olarak da kullanıldığını ifade etmiştir. On iki 4. sınıf öğretmeni ile Duban (2016) tarafından yürütülen çalışmada da araştırmacı, öğretmenlerin ev ödevlerine benzer amaçlarla başvurduğunu belirlemiş ve bu doğrultuda öğrencilerin ev ödevlerini yaparken yardım almasının, ödevin kontrol edilmesinin ve ev ödevi sorumluluğu kazandırılmasının gerektiğini ifade etmiştir. Öcal (2009) tarafından yürütülen bir başka çalışmada da ödevlerin sıklıkla pekiştirme, araştırma ve sorumluluk bilinci geliştirme davranışlarının kazandırılması amaçlarını taşıdı ğ görülmüştür. Çalışmaya katılan öğretmen, ödevlere mutlaka dönütler verildiğini; kimi zaman öğrencilerin birbirlerinin ödevlerini incelediğini ifade etmiştir. Öğretmenin ifadeleri, Demirbaş (2011) tarafından yürütülen ilkokuldaki ödev uygulamalarının değerlendirilmesinin amaçlandığı çalışmanın bulguları ile de benzerlik göstermektedir; çalışmaya katılan öğretmenlerin \% 98,4’ü gibi büyük bir çoğunluğunun ödevleri kontrol ettiğini ifade etmiştir. Büyüktokatlı (2009) da çalışmalarının bulgularından hareketle öğretmenlerin amacına uygun ödevler verilmesinin ve dönüt sağlanmasının gerekliliği vurguladıklarını ifade etmiştir. Öğretmenin ödevi makul miktarda tutmaya özen göstermesi de Oluşum (2016)'un çalışma bulguları ile uyum göstermektedir.

Genel olarak değerlendirilecek olursa, katılımcı öğrencilerden hiçbiri ödevin faydasız bulduğuna yönelik görüş öne sürmemiş, ödevi yapmaktan hoşlanmadığını ifade etmemiş ve hepsi faydalı bulduklarını belirtmiştir. Bu durum alan yazındaki öğrencilerin ev ödevlerine yönelik tutumlarını saptama amacıyla gerçekleştirilmiş ve bireylerin ev ödevlerine yönelik olumlu tutuma sahip olduğu bulgusuna ulaşılan pek çok çalışmayla benzerlik göstermektedir (Hallam, 2004; Coşkun, Gelen ve Kan, 2009; Safont-Mottay, Oubrayrie-Roussel ve Lescarret, 2009; Öcal,2009; Sarıgöz, 2011; Atl1, 2012). Öğrencilerin üç ödeve yönelik genel görüşleri, ödevleri betimlemek 
için kullandıkları sözcükler ve sıklıklarına bağlı olarak incelenmiştir. Buna göre katılımcı öğrenciler, araştırma yapmalarını gerektiren birinci ödevi daha çok ibret verici/üzücü olarak betimleme eğilimindeyken betimlemek için en az başvurdukları sözcükler, "bilgilendiri/eğitici” olmuştur. Söz konusu ödevi diğer ödevlerden farklı olarak "araştırma” şeklinde betimleyen bir katılımcı da mevcuttur. İkinci ödevi betimlemek için öğrenciler yine en sık “üzücü/ibret verici” gibi duygusal ifadeler kullanmışlardır. Bu tanımlamayı "keyifli/eğlenceli” ifadeleri takip etmiştir. Bireyler bu ödevi, ilk ödeve benzer şekilde en az sıklıkla "öğretici/faydalı" olarak betimlemektedir. Öğrencilerin test çözmelerini gerektiren üçüncü ödevi betimlemek için seçtikleri sözcükler sıklıkları açısından farklılık göstermektedir. Buna göre bireyler test çözme ödevi için betimlemelerinde kolaylık/zorluk yönünü ön plana çıkarmakta; daha az sıklıkla da ödevi "öğretici/faydalı” olarak betimlemektedir. Bu noktada, bireylerin spesifik ifadeleri de incelendiğinde, soru çözmelerini gerektiren ödevleri öğrencilerin daha çok başarı, sınava hazırlanma, yeni bilgiler edinme yönü ile algıladıkları görülmüştür. Bu ödev için belli trafik kurallarına örnekler vermemekle beraber daha çok sınav ve başarı odaklı algılama yoluna gitmiş ve bu sebeple daha çok "faydalı/öğretici" bulduklarını ifade etmiştir. Ancak gazeteden araştırma yapmalarını ve kompozisyon yazmalarını gerektiren ödevde öğrencilerin ifadeleri trafik kazalarının üzücü olmasının yanı sıra, trafik kurallarının neden gerekli olduğunu farkındalık kazanmaları; "kırmızı ışıkta geçmeme", "aşırı hız yapmama" gibi belirgin kurallara uyulmaması hâlinde yaşanabilecek olumsuzlukların somutlaşması gibi noktalarda katkı sağladıklarını yansıtmaktadır. Bu noktada ilk iki ödevin okulda edinilen bilgilerin gündelik hayattaki yansımalarını görebilme imkânı verdiği, konuya ilgi uyandırdığı; testin ise daha çok öğrencilerin alışkın olduğu sınav temposuna hitap ettiği ve not kaygısının göstergesi olduğu görülmektedir. Ancak bu noktada dikkat çekici bir diğer bulgu, test çözmelerini gerektiren ödeve yönelik daha fazla öğrencinin bilgilendirici ifadesini kullanmasıdır. Öğrencilerin her üç ödevin öğrencilere sağladığı katkılara yönelik görüşleri incelendiğinde ise bunların betimlemeleri ile benzerlik göstermektedir. Öğrenciler ödevlerden bilgi birikimlerini artırma, farkındalık kazanma ve araştırma yapma gibi farklı beceriler geliştirme gibi katkılar sağladıklarını ifade etmişlerdir.

Öğrencilerin ödevleri betimlemek için kullandıkları sözcükler, öğretmenin ödevleri veriş amaçlarının genel olarak öğrencilerde karşılığını bulduğunu göstermektedir. Öğretmenin tipik olarak başvurduğu ve çalışma kapsamında da uygulanan üç ödevin veriş amaçları sırasıyla, merak ve farkındalık kazandırmak, kendilerini ifade etme olanağ bulmalarını sağlamak ve işlenen konuyu pekiştirmektir. Öğretmen, her yeni ünitede belirtilen amaçlara yönelik olarak ev ödevi vermektedir. Öğrencilerin yalnızca kompozisyon yazmaları gereken ikinci ödevde, öğretmenin beklentilerini karşılamadıkları görülmüştür. Öğretmenin yeni bir ürün ortaya koymaları beklentisi ile verdiği ödevde öğrenciler gazete haberlerini özetlemeyi tercih ettiklerini belirtmiş ve yaratıcılık, yeni ürün ortaya koyma gibi ifadeler kullanmamışlardır. Buna bağlı olarak da ödev için en sık farkındalık anlamındaki kazanımlarını dile getirmişlerdir. Bu bulgulardan hareketle, öğrencilere belli konularda farkındalık kazandırmayı, dikkatlerini belli bir konuya toplamayı ya da okulda edindikleri bilgilerin günlük hayatta uygulanabilirliğinin anlaşılması amacıyla verilen araştırma ödevlerinin amacına hizmet ettiği ifade edilebilir. Ancak öğrencilerin özgünlük gerektiren ödevlere aşina olmadıkları görülmüştür. Bu bulgu, alan yazına bağlı beklenen bir durumdur. Buna göre hayatta daha uygulanabilir ödevleri öğrenciler açısından alıştırma yapma, test çözme gibi uygulamalardan daha az bilgilendirici olmakla birlikte daha eğlenceli bulmaktadır (Alleman, Knighton, Brophy, Ley ve Botwinski, 2010). Bu bulgu aynı zamanda Ersoy ve Anagün (2009) tarafından sınıf öğretmenleri ile fen ve teknoloji dersine yönelik olarak yürütülen çalışma ile de desteklenmektedir; söz konusu çalışmada araştırmacı en az sıklıkla öğrencilerin yaratıcılıklarını sergilemeleri gereken ödevlere başvurulduğu bulgusuna ulaşmıştır. Öğrenciler, soru çözme uygulamalarına daha alışkın oldukları için bu tür ödevleri daha faydalı bulmaktadır. Ancak ifadeleri genel olarak incelendiğinde, bu tür ödevlerin onları bilgileri daha çok not alma ya da başarılı olmanın bir aracı olarak gördüklerini göstermiştir. Bu bilgiler ışığında, ödev çeşitliliğinin sağlanmasının, soru çözmenin yanı sıra araştırma yapmayı gerektiren ödevlerin verilmesinin okulda edinilen bilgilerin anlamlılığını ve gündelik hayata uygulanabilirliğini sezdirme ve farkındalık kazandırma anlamında faydalı olacağı ifade edilebilir. Kaplan (2006) da benzer şekilde geleneksel ödevlerdense farklı ödev türlerinin uygulanmasının öğrencilerin ilgilerini daha artırdığını ve olumlu tutum geliştirmelerini sağladığını belirtmiştir.

Çalışmanın bulguları, öğrencilerin ödev yaparken genellikle anne- babalarından yardım aldıklarını göstermektedir. Öğrenciler, velilerinin ödev yapma sürecindeki rolünü ödev türüne bağlı olarak değişmeksizin genellikle olumlu olarak nitelemişlerdir. Bu bulgu alan yazınla paralellik göstermektedir (Safont-Mottay, Oubrayrie-Roussel ve Lescarret, 2009). Buna göre öğrenciler büyük oranda anne babalarının ya da diğer aile bireylerinin ev ödevlerinde onlara yardımcı olmasının kendilerini iyi hissettirdiğini, önemsendiklerini fark ettirdiğini ifade etmiştir. Öğrenciler ayrıca başkalarından yardım aldıkları ödevin doğruluğundan emin olduklarını ifade etmişlerdir. Benzer şekilde öğretmen, velilerin ödevde öğrencilere yardımcı olmasının veli-öğrenci etkileşimini desteklediği ve öğrencilere farklı bir kaynaktan bilgi edinme imkânı sunduğunu öngörmektedir. Cooper (2007) da ödevlerin velilerin ve çocukları ile etkileşimde bulunma imkânı olarak tanımlamaktadır. Bu noktada öğretmenin beklentilerinin, öğrencilerdeki yansıması ile benzer olduğu ifade edilebilir. Az sayıda öğrenci ise ödevi yardım almadan tamamlamalarının onlara kendilerini daha özgüvenli hissettirdiğini ifade etmiştir. Yalnızca öğretmenin aileden yardım almanın öğrencilere farklı bir bakış açısı kazandıracağına yönelik öngörüsü öğrencilerde karşılığını 
bulmamıştır. Bunun temelinde genel olarak öğrencilerin konuyu kolay bulmaları yatabilir; bu sebeple konuyu kavramak için desteğe ihtiyaç duymamış ve dersi yeterli bulmuş olabilirler. Sekizinci ve dokuzuncu sınıf öğrencileri ile Trautwein ve Lüdte (2009) tarafından yürütülen bir başka çalışmada ise ev ödevi yapma sürecine anne babaların dâhil olmasının öğrencinin ödevi tamamlama davranışı ya da güdülenmesi ile ilişkili olmadığı bulgusuna ulaşmıştır. Bu araştırma sorusuna yönelik alan yazındaki bazı çalışmalardan farklı sonuçlara ulaşılması katılımcıların daha düşük sınıf düzeyinden olması ile açıklanabilir. Bu bulgudan hareketle, dördüncü sınıfta bireyler tarafından velilerin ev ödevi sürecinde daha aktif rol almasının daha olumlu karşılandığ ifade edilebilir.

Bu çalışma sadece 4. sınıf “Trafik Güvenliği”” dersi kapsamındaki üç ödev türüne yönelik olarak yürütülmüştür. Başka bir çalışma otantik uygulamalar gerektiren ödevler üzerinden gerçekleştirilebilir. Ayrıca çalışmanın daha geniş bir örneklemle nicel araştırma yaklaşımı ile yürütülmesi bulguların genellenebilirliğine yönelik anlamlı katkılar sunabilir. Bunun yanı sıra, ev ödevlerine yönelik öğretmen beklentilerinin öğrencilerdeki yansımaları ile örtüşüp örtüşmediğinin belirlenmesi; böylelikle ev ödevi uygulamalarının bir portresinin çıkarılması için farklı dersler kapsamında verilen ödevlere yönelik de çalışmalar yürütülmelidir. Çalışma bulgularından hareketle uygulamacılara yönelik olarak ise farklı türlerde ödevlerden yararlanılması; öğrencilerin öğrendiklerini anlamlandırabilmeleri için soru çözmelerini gerektiren ödevlerin yanı sıra araştırma yapmalarını ya da yeni ürünler ortaya koymalarını gerektiren ödevler uygulamalarının tercih edilmesi önerilebilir. 


\section{EKLER}

\section{Ek.1. Öğretmen Görüşme Soruları}

1- Ev ödevleri uygulamalarınızı anlatır mısınız?

2- Ev ödevlerini ne sıklıkla veriyorsunuz?

3- Ev ödevlerini hangi amaçlarla veriyorsunuz?

4- Ev ödevini verirken öncelikle nelere dikkat etmektesiniz?

5- Ev ödevlerini nasıl kontrol etmekte ve değerlendirmektesiniz?

6- Ev ödevlerinde velinin rolünü nasıl tasvir edersiniz?

\section{Ek.2. Öğrenci Görüş Formu Soruları}

Bu hafta öğretmeniniz sizden ödev olarak gazetelerden kestiğiniz trafik kazası fotoğrafları ile ilgili kompozisyon yazmanızı istedi. Aşağıdaki soruları bu ödevi düşünerek yanıtlayınız lütfen.

1) Ev ödevi.... gibiydi çünkü.

2) Sizce bu ev ödev faydalı mı? Size ne kazandırdığını düşünüyorsunuz?

3) Ödevi yaparken ne kadar keyif aldığınızı 0'dan 4'e kadar puanlasanız kaç puan verirdiniz?

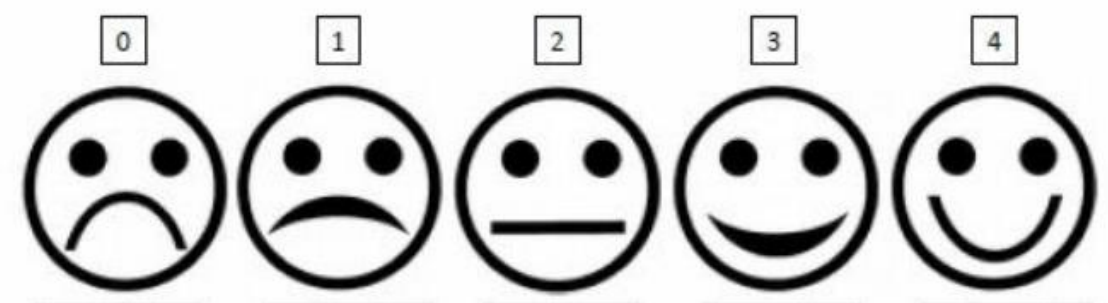

4) Puanlamanızda ne etkili oldu?

5) Yaptı̆̆ınız ödevde sizi zorlayan durumlar neler?

6) Ödev yaparken başkalarından yardım aldınız mı? Bu size ne hissettirdi? 


\section{KAYNAKÇA}

Akın, Z. (1998). Ödevin öğrenci başarısına etkisi. Yayınlanmamış Yüksek Lisans Tezi, Pamukkale Üniversitesi, Denizli.

Alleman, J., Knighton, B., Brophy, J., Ley, R., ve Botwinski, B. (2010). Homework done right: Powerful learning in real-life situations. Corwin Press.

Aslanoğlu, A. E., ve Kutlu, Ö. (2007). PIRLS 2001 Türkiye verilerine göre 4. sınıf öğrencilerinin okuduğunu anlama becerileriyle ilişkili faktörler. Eğitim Bilimleri Araștırmaları Dergisi, 5(2), 1-18.

Atılgan, H., Kan, A. ve Doğan, N. (2007). Eğitimde ölçme ve değerlendirme. Ankara: Anı Yayıncılık.

Atlı, S. (2012). 4. sinıf fen ve teknoloji dersinde ev ödevlerinin öğrencilerin kavram öğrenme düzeylerine, akademik başarılarına ve ev ödevlerine yönelik tutumlarına etkisi, Dicle Üniversitesi Ziya Gökalp Eğitim Fakültesi Dergisi, 18, 1-16.

Babadoğan, C. (1990). Ev ödevlerinin eğitim programları içindeki yeri. Ankara Üniversitesi Eğitim Bilimleri Fakültesi Dergisi. 23(2), 745-767.

Babadoğan, C. (2003). Ev ödevi mi, ödev ev mi?. Çoluk Çocuk: Ayllk Anne Baba Eğitimci Dergisi, 28 (7), 1-2.

Bennett, S. \& Kalish, N. (2006). The case against homework: how homework is hurting our children and what we can do about it. New York: Crown Publisher.

Bent-Hill, C., Boswell, R., Byers, J., Cohen, N., Cummings, J. \& Leavitt, B. (1988). Relationship of Academic Performance to Parent Estimate of Homework Time. 13 Kasim 2014 tarihinde http://eric.ed.gov/?id=ED300885 adresinden alınmıştır.

Berberoğlu, G. (2005). Turkey-Education Sector Study: Sustainable Pathways to an Effective, Equitable and Efficient Education System for Preschool Through Secondary School Education. 31 Kasım 2014 tarihinde http://siteresources.worldbank.org/INTTURKEY/Resources/3616161142415001082/ESS_Main_Report_V1.pdf adresinden alınmıştır.

Berberoğlu, G. (2008). Ev ödevlerinin öğrenme ile ilişkisi, CITO Eğitim: Kuram ve Uygulama, Tanıtım Sayısı, 50-54.

Berg, B. L., \& Lune, H. (2011). Qualitative research methods for the social sciences. U.S.A.: Pearson Higher Ed.

Büyüktokatlı, N. (2009). Illkögrretimde ev ödevi uygulamalarına ilişkin öğretmen görüşlerinin incelenmesi. Yayımlanmamış Yüksek Lisans Tezi,. Selçuk Üniversitesi, Konya.

Cooper, H. (2003). Supporting children's homework assignments in afterschool programs. G.G. Noam, G. Biancarosa, N. Dechausay (Eds), Afterschool Education: Approaches to an emerging field içinde, 117121, Cambridge: Harward Education Press.

Cooper, H. (2007). The battle over homework: common ground for administrators, teachers and parents. California: Corwin Press.

Cooper, H. \& Hedges, L.B. (1994). Handbook of research synthesis. New York: Russel SAGE Foundation.

Cooper, H., Lindsay, J.J. , Nye, B. \& Greathouse, S. (1998).Relationship among attitudes about homework amount of homework assigned and completed, and student achievement. Journal of Educational Psychology, 90, 70-83.

Cooper, H., Robinson, J. C. \& Patall, E. A. (2006). Does homework improve academic achievement a synthesis of research, 1987-2003. Review of Educational Research, 76(1), 1-62.

Corno, L. (1996). Homework is a complicated thing. Educational Researcher, 25, 27-30.

Coşkun E., Gelen İ. ve Kan, M. O. (2009), Türkçe dersindeki performans ödevleri konusunda öğretmen ve öğrenci görüşlerinin değerlendirilmesi. Mustafa Kemal Üniversitesi Sosyal Bilimler Enstitüsü Dergisi. 11 (6), $22-55$.

Cresswell, J.W. (2014). Research design: qualitative, quantitative and mixed methods approaches. U.S.A.: SAGE Publications.

Çetinkaya, A. (1992). Adana ili merkez ortaokullarında ev ödevlerine ilişskin karşıllaşılan sorunlar. Yayınlanmamış Yüksek Lisans Tezi, Çukurova Üniversitesi, Adana.

Demirbaş, A. (2011). İlköğretim Okullarındaki (1-5. Sınıf) Ödev Uygulamalarının Değerlendirilmesi Araştırması. Millı̂ Eğitim Bakanlığı, Eğitimi Araştırma ve Geliştirme Dairesi Başkanlığı, Ankara.

Duban, N. (2016). Sınıf öğretmenlerinin ev ödevleri hakkındaki görüşleri. International Journal of Education Technology and Scientific Researches, 1(1), 55-67.

Epstein, J. L. \&Becker, H. J. (1982). Teacher reported practices of parent involvement: Problems and possibilities. The Elementary School Journal, 83(2), 103-113.

Ersoy, A. ve Anagün, Ş. S. (2009). Sınıf öğretmenlerinin fen ve teknoloji dersi ödev sürecine ilişkin görüşleri. Necati Bey Eğitim Fakültesi Elektronik Fen ve Matematik Eğitim Dergisi (EFMED), 3(1), 58-79.

Fraenkel, J., Wallen, N., \& Hyun, H.H. (2012). How to design and evaluate research in education. Boston: McGraw Hill.

Good, C. V. (1959). Dictionary of education. New York: McGraw-Hill. 
Hallam, S. (2004). Current findings homework: The evidence. British Educational Research Association Research Intelligence, 89, 27- 29.

Hizmetçi, S. ve İflazoğlu, A. (2006). İlköğretim birinci kademe sınıf öğretmenlerinin ev ödevleri hakkındaki görüşlerine ilişkin nitel bir çalışma örneği. Ulusal Sını Öğretmenliği Kongresi Bildiri Kitabı, 427-434. Ankara: KÖK Yayıncılık.

Kaplan, B. (2006). İlkögrretim 6. Sınıf “yaşamımızı yönlendiren elektrik”' ünitesinde ev ödevi verilmesinin ögrenci başarısına ve kavram ögrenmeye etkisi. Yayınlanmamış Yüksek Lisans Tezi, Marmara Üniversitesi, İstanbul.

Kidwell, V. (2004). Homework. London: Continuum.

Kohn, A. (2006). The homework myth: why our kids get too much of a bad thing. London: Da Capo Lifelong Books.

Kutlu, Ö., Yıldırım, Ö., Bilican, S. ve Kumandaş, H. (2011). İlköğretim 5. sınıf öğrencilerinin okuduğunu anlamada başarılı olup-olmama durumlarının kestirilmesinde etkili olan değişkenlerin incelenmesi. Ĕgitimde ve Psikolojide Ölçme ve Değerlendirme Dergisi, 2(1), 132-139.

Lee, J. \& Pruitt, K.W. (1979). Homework assignment: classroom games or teaching tools. The Clearing House, 53, 31-35.

Marzano, R, \& Pickering, D. (2007). The case for and against homework. Educational Leadership, 64(6), 74-79.

MEB. (2013). İlkokul ve ortaokul haftalık ders çizelgesi. Ankara: Milli Eğitim Bakanlığı.

MEB. (2018). Trafik güvenliği ders öğretim programı: 4. sınıflar için. Ankara: Milli Eğitim Bakanlı̆̆ı.

Miles, M. B. \& Huberman, A. M. (1994). Qualitative data analysis. London: Sage.

NCTM (National Council of Techers of Mathematics). (2002). Effective Homework Assignment. 29 Kasim 2015 tarihinde

https://www.nctm.org/uploadedFiles/Research_News_and_Advocacy/Research/Clips_andBriefs/Brief $\% 20 \% 20$ Effective \%20Homework\%20Assignments.pdf adresinden alınmıştır.

NCTM (National Council of Teachers of Mathematics). (2008). Homework: What Research Says? 13 Kasım 2016 tarihinde

http://www.nctm.org/uploadedFiles/Research_News_and_Advocacy/Research/Clips_and_Briefs/Brief \%20-\%20Homework\%20What\%20Research\%20Says.pdf adresinden alınmıştır.

Oluşum, B.(2016). 4. sınıf Türkçe dersinde verilen ev ödevlerinin incelenmesi. Yayımlanmamış Yüksek Lisans Tezi, Hacettepe Üniversitesi, Ankara.

O'Neill, J. (2008). Is Homework Helpful or Harmful?. 13 Kasım 2016 tarihinde http://www.findingdulcinea.com/news/Americas/September-08/Is-T.Homework-Helpful-orHarmful.html adresinden alınmıştır.

Öcal, S. (2009). Illkögretim 4. ve 5. sinıf öğrencilerinin ev ödevlerine yönelik tutumlarının oluşmasında ailelerin ve ögretmenlerin rolü. Yayınlanmamış Yüksek Lisans Tezi, Mustafa Kemal Üniversitesi, Hatay.

Patton, MQ. (1999). Enhancing the quality and credibility of qualitative analysis. HSR: Health Services Research. 34(5) Part II, 1189-1208.

Paulu, N. (1998). Helping Your Children With Homework: A Guide For Teachers. 14 Kasım 2016 tarihinde http://www2.ed.gov/PDFDocs/hyc.pdf adresinden alınmıştır.

Safont-Mottay, C., Oubrayrie-Roussel, N. \& Lescarret, O. (2009). Parent-child Dyad's representatilons regarding homework and primary pupils views of parent involvement in homework. R. Deslandes (Ed.), International Perspectives on Students Outcome and Homework içinde, 111-123, New York: Routledge.

Sarıgöz, O. (2011). Ortaöğretim öğrencilerinin kimya derslerinde verilen ev ödevleri hakkındaki düşüncelerinin değerlendirilmesi. EJOVOC: Electronic Journal of Vocational Colleges, 1(1), 80-87.

Stewart, C.J., \& Cash, W.B. (1985). Interviewing: principles and practices. Dubuque IO: Wm. C. Brown Pub.

Sullivan, M. H., \& P. V. Sequera, (1996). The impact of purposeful homework on learning. Clearing Hause, 69 (6), 346-349.

Trautwein, U., \& Lüdtke, O. (2009). Predicting homework motivation and homework effort in six school subjects: The role of person and family characteristics, classroom factors, and school track. Learning and Instruction, 19(3), 243-258.

TTK . (1989). Ders Dışı Eğitim ve Öğretim Faaliyetleri Genelgesi. Ankara: Talim ve Terbiye Kurulu.

Walberg, H. J. \& Paik, S. J. (1999). Effective Educational Practices. 14 Aralı 2014 tarihinde http://www.ibe.unesco.org/publications/EducationalPracticesSeriesPdf/prac03e.pdf $\quad$ adresinden alınmıştır.

Weber, R.P. (1990). Basic content analysis. Beverly Hills, CA: Sage.

Yapıc1, N. (1995). Illkokullarda ögretmen, ögrenci ve velilerin ev ödevi konusundaki görüşlerinin belirlenmesi. Yayınlanmamış Yüksek Lisans Tezi, Ankara Üniversitesi, Ankara.

Yıldırım, A. ve Şimşek, H. (2013). Sosyal bilimlerde nitel araştırma yöntemleri. Ankara: Seçkin Yayıncılık.

Yin, R.K.(2003). Case study research: Design and methods. Thousand Oaks, CA: Sage. 


\section{Çağla ALPAYAR}

Yücel, A.S. (2004). Ortaöğretim düzeyindeki öğrencilerin kimya derslerinde verilen ev ödevlerine karş1 tutumlarının incelenmesi. Gazi Ĕ̌itim Fakültesi Dergisi, 24(1), 147-159. 


\section{EXTENDED ABSTRACT}

\section{Introduction}

In Turkey, homework is a common practice in especially primary schools. However, the studies have contradicting results about the effectiveness of the homework. The reason of this contradiction may be that the teacher's expectations do not match the practice of the homework. Therefore, it is a necessity to find out whether the teacher's expectations from homework are correspond to the students' opinions. Based on this necessity, the purpose of the study is to determine the opinions of students and teachers about homework applied to the $4^{\text {th }}$ grade primary school students in this research.

1- Sub-Questions for Teacher's Opinions:

1.1. How is homework applied in the 4 th grade courses?

1.2. Which acquisitions the teacher foresee from the homework assigned to the 4 th grade students?

1.3. How does the 4th grade teacher explain the parents' role in homework?

2- Sub-Questions for Students' Opinions:

2.1. How do the the 4 th grade students describe the homework?

2.2. What are the 4th grade students' opinions about their acquisitions from the homework?

2.3. What are the opinions of the 4th grade students regarding the role of the parents in homework?

3- Sub-Questions About Similarities and Differences Between Teacher' and Students' Opinions:

3.1. Is the teacher's expectation is similar to the students' opinions about the acquisition of homework?

3.2. Is the teacher' expectation similar to the students' opinions about the parental role in homework?

\section{Method}

This is a case study conducted to investigate a typical portrait of homework from both a teacher's and students' perspectives. The study group determined by purposive sampling was a fourth grade class with 25 students studying in 2016-2017 and their teacher. They were selected by taking into consideration of their availability and the frequency of homework practice. Moreover, the application of the homework was a typical representation of the requirement of the in 4th grade Curriculum of Elementary Schools in Turkey.

The data was collected in three stages after consecutive different homework practices of "Traffic Safety" course. Orderly: the students cut a newspaper clipping about the traffic accidents, wrote a paper about their feeling and thoughts related to the new, and solved a test whose items were about the traffic rules. The researcher asked the students to fill the interview forms with six open-ended questions after submission of each homework. The teacher's opinions were examined by face-to-face semi-structured interviews after every three homework the teacher's opinions. The questions of the interviewed were constructed before the interview based on the previous studies.

\section{Findings, Discussion and Results}

The teacher stated that the homework was applied as three periods of time within the themes for each course instructional program. They were applied at the beginning of the unit, during the unit and at the end of the unit. They were grouped in terms of the objectives that were orderly preparation for the course, repeat, and evaluation of the instructional process similar to Cooper's (2007) approach. In the first group of homework, the teacher intended the students to make research so they prepared for the new course topic. In the following process, the students repeat the content of the course after class and execute a new product. In the final group of homework, the teacher evaluates the students whether they reached the objective. On the other hand, the teacher used the homework as a tool of the connection between the children, parents and school practices as Cooper (2003) emphasized. According to her, parent's involvement to the homework process make the students feel themselves valuable. Lastly, the teacher stated that she provided feedback to the students. As the one by one feedback was time-consuming, the students controlled each other's homework. So that only the commonly omitted or incorrectly answered questions were solved during class. She controlled the other homework by taking into account their capability, originality, and effort.

The students' opinions about homework were gathered into five categories as Easy/Simple, Enjoyable/Joyful/Good/Nice, Depressing/ Exemplary and Research. The students' emotional reactions were more 
common in the first two homework while they tended to emphasize the informing way of the third homework. They found the second homework enjoyable and depressing. The most common description for the third homework was the statements related to the difficulty of the task; however, for others, the difficulty was not such a dominant feature The students' opinions about the acquisition from homework were gathered in three categories as knowledge, awareness and different skills. The students stated that they learned about the traffic rules thanks to the given all homeworks. Many studies supported the students' positive attitude towards homework (Atl, 2012; Coşkun, Gelen ve Kan, 2009; Hallam, 2004; Öcal,2009; Safont-Mottay, Oubrayrie-Roussel ve Lescarret, 2009; Sarıgöz, 2011). In the category of gaining awareness, the students' statements highlighted their recognition of car accidents, the necessity and importance of traffic rules.

The students' and the teacher's opinions about homework were similar in terms of the acquisition from homework. Both shareholders found homework beneficial because of its contribution to the students' knowledge, awareness, and development of different skills except the second homework. For the latter, the teacher expected the students to utilize their creativity and use their own words to reflect their feelings. However, her expectations did not coincide the students' perspective since the students did not describe the second homework as a tool to state an opinion or make a production. The reason for this difference was that the students tried to summarize the news instead of using their own ideas and words. Both shareholders state the second homework as a tool to repeat the class. For the third one, the students' general statements were related to the difficulty level of the questions and academic objectives. Some students receive help from their parents while the others did not. Most of the students stated that spending time with parents make them feel happy while only small number of them did not ask parents' help. All in all, the teacher's expectation about the function of homework as a tool of promoting communication between students and parents was met. 


\section{ETIKK BEYANNAME}

Yapılan bu araştırmanın yazım sürecinde bilimsel ve etik kurallara tüm araştırmacılar tarafından uyulmuş, farklı eserlerden yararlanması durumunda atıfta bulunulmuş, kullanılan verilerde herhangi bir tahrifat yapılmamış, araştırmanın tamamı veya bir kısmı farklı bir akademik yayın platformunda yayınlatılmak üzere gönderilmemiştir. Tüm bu durumlardan araştırmada ismi bulunan yazarların bilgisi olduğunu ve gerekli kurallara uyulduğunu beyan ederim. 03/03/2020

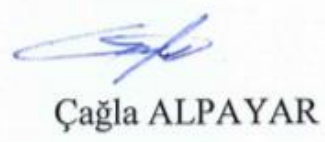

